\title{
Near-Infrared Luminescence from Visible-Light-Sensitized Ruthenium(II)-Neodymium(III) Heterobimetallic Bridged Complexes Containing Alkoxy(silyl) Functional Groups
}

\author{
Rafael M. Sábio, ${ }^{\circledR *, a, b}$ Silvia H. Santagneli, ${ }^{b}$ Marie Gressier, ${ }^{a}$ José M. A. Caiut, $^{c}$ \\ Wallance M. Pazin, ${ }^{d}$ Robson R. Silva, ${ }^{e}$ Sidney J. L. Ribeiro ${ }^{b}$ and Marie-Joëlle Menu ${ }^{a}$ \\ ${ }^{a}$ Centre Inter-universitaire de Recherche et d'Ingénierie des Matériaux (CIRIMAT), \\ Université Toulouse 3 - Paul Sabatier, 118 route de Narbonne, 31062 Toulouse, France \\ ${ }^{b}$ Instituto de Química, Universidade Estadual Paulista (Unesp), CP355, 14801-970 Araraquara-SP, Brazil \\ 'Departamento de Química, Faculdade de Filosofia, Ciências e Letras de Ribeirão Preto, \\ Universidade de São Paulo, 14040-901 Ribeirão Preto-SP, Brazil \\ ${ }^{d}$ Departamento de Física, Faculdade de Filosofia, Ciências e Letras de Ribeirão Preto, \\ Universidade de São Paulo, 14040-901 Ribeirão Preto-SP, Brazil \\ ${ }^{e}$ Department of Chemistry and Chemical Engineering, Chalmers University of Technology, \\ SE-41296 Gothenburg, Sweden
}

\begin{abstract}
New infrared emitting d-f (ruthenium(II)-neodymium(III)) heterobimetallic complexes with alkoxy(silyl) functional groups have been prepared. Visible excitation evidenced energy transfer processes from the ruthenium(II) donor to neodymium(III) acceptors leading to infrared emission. Energy transfer rates $\left(\mathrm{k}_{\mathrm{EnT}}\right)$ and efficiency of energy transfer $\left(\eta_{\mathrm{EnT}}\right)$ are, respectively, $0.61 \times 10^{7} \mathrm{~s}^{-1}$ and $44 \%$ for $\mathrm{RuL}^{1}-\mathrm{NdL}^{3}$ complex. Larger values of $\mathrm{k}_{\mathrm{EnT}}\left(3.04 \times 10^{7} \mathrm{~s}^{-1}\right)$ and $\eta_{\mathrm{EnT}}(84 \%)$ were detected for $\mathrm{RuL}^{2}-\mathrm{NdL}^{4}$ complex. $\mathrm{RuL}^{1}-\mathrm{NdL}^{3}$ and $\mathrm{RuL}^{2}-\mathrm{NdL}^{4}$ complexes were fully characterized by elementary analysis (EA), mass spectrometry (MS), Fourier transform infrared spectroscopy (FTIR) and Fourier transform Raman spectroscopy (FT-Raman). Total correlation spectroscopy (TOCSY1D), ${ }^{1} \mathrm{H}\left\{{ }^{13} \mathrm{C}\right\}$ heteronuclear single quantum correlation (HSQC) and ${ }^{1} \mathrm{H}\left\{{ }^{13} \mathrm{C}\right\}$ heteronuclear multiple bond correlation (HMBC) nuclear magnetic resonance (NMR) analyses were also carried out to characterize $\mathrm{NdL}^{3}$ and $\mathrm{RuL}^{1}-\mathrm{NdL}^{3}$ complexes. The presence of trialkoxysilyl-substituted ligands would allow further grafting onto any silica or silicated surface aiming at applications as new luminescent near infrared (NIR)-emitting biosensors or biomarkers.
\end{abstract}

Keywords: ruthenium(II), neodymium(III), silylated heterobimetallic complexes, d-f energy transfer, grafting trialkoxysilyl group, visible and NIR luminescent complexes

\section{Introduction}

The design and assembly of heterobimetallic complexes based on d-block metalloligands with near-infrared (NIR) emitting lanthanides (Ln) have attracted interest in the recent years due to potential applications in non-invasive bio-analysis and bio-imaging. ${ }^{1-6}$ Given the inherent low molar absorption coefficients of lanthanide(III) ions $\left(\varepsilon<10 \mathrm{~mol} \mathrm{~L}^{-1} \mathrm{~cm}^{-1}\right)$, d-block chromophores serve as effective light-harvesting groups to sensitize Ln-emissive centres. ${ }^{1}$ Beyond that, most of lanthanide complexes require excitation in the ultraviolet (UV) region, which is

*e-mail: rafaelmsabio@gmail.com harmful for the biological systems. The aromatic residues of proteins and deoxyribonucleic acid (DNA) absorb in competition with the chromophores. In addition, the UV excitation cause damages in these biological systems. ${ }^{1}$ One of the strategies to overcome these limitations consists on using d-block chromophores as antenna groups to sensitize luminescence from lanthanide(III) ions with low energy f-f excited states.

Typically, ruthenium(II) complexes displaying polypyridine bridging ligands are used to sensitize NIR emitting lanthanide ions through the strong absorption of the visible light by ${ }^{3} \mathrm{MLCT}$ (MLCT = metal-to-ligand charge transfer) excited state. ${ }^{1}$ These d-block chromophores, with relatively low ${ }^{3} \mathrm{MLCT}$ states, act as good energy donors 
to f-f levels of praseodymium(III), neodymium(III), erbium(III) and ytterbium(III). In particular, $\left[\mathrm{Ru}(\mathrm{bpy})_{3}\right]^{2+}$ (bpy $=2,2^{\prime}$-bipyridine) possesses a broad and strong absorption in the visible and a low triplet state (energy of triplet state $=17400 \mathrm{~cm}^{-1}$ ) that can allow lanthanide(III) to be efficiently excited. ${ }^{1}$ Authors ${ }^{7}$ reported the use of distinct lengthy bridging ligands (saturated or unsaturated) between energy donor (d-block) and acceptor fragments (f-block) and concluded that the role of ligands is vital in determining the ruthenium(II) $\rightarrow$ lanthanide(III) energy transfer (EnT), and the energy level of triplet state was related with the bridging processes. ${ }^{7}$

Pyridine derivate ligands can also serve as bridging ligands to prepare ruthenium(II)-lanthanide(III) heterobimetallic d-f complexes. Specifically, 2,2'-bipyrimidine (bpmd) is widely used to synthesize planar heterobimetallic complexes since it can easily coordinate two metal centers through four nitrogen sites leading to a relatively short metal-metal distance. As a result, an efficient channel is available for energy and electron transfer from d-block chromophores in the visible region to NIR emitting lanthanide(III) centres. ${ }^{7-14}$

Despite the examples of ruthenium(II)-lanthanide(III) heterobimetallic complexes being reported in the last few years, their use as luminophors for biosensors or biomarkers is yet scarce. The most likely reasons are their low water solubility and relatively weak luminescence. ${ }^{15}$ As an alternative to explore the potentialities of such heterobimetallic complexes in biological applications, these complexes need to be functionalized to be covalently anchored on silica nano and microparticles. We have demonstrated the preparation of bipyridine and diketone derivative ligands such as bpy-Si (4-methyl-4'-[methylamino3 (propyltriethoxysilyl)]-2,2'-dipyridine) ${ }^{16}$ and TTA-Si (4,4,4-trifluoro-2-(3-(trimethoxysilyl)-propyl)1-(2-thienyl)-1,3-butanedione) ${ }^{17}$ appropriately substituted by a trialkoxysilyl groups. Sequentially, silylated ruthenium(II) and lanthanides(III) complexes have been isolated and grafted at the surface ${ }^{16-21}$ or embedded ${ }^{17,18,21,22}$ in nanosized silica. These previous results stimulated us to design d-f heterobimetallic complexes by introducing silylated appropriated ligands, bpy-Si or TTA-Si, involving NIR emitting lanthanides as neodymium(III) and bipyrimidine as bridging $d-f$ ligand.

In this way, two routes were employed to obtain two types of dyads based on the chemistry of bipyridine ruthenium(II) and diketonate neodymium(III) derived complexes according to the position of the silylated functional group. For the sake of brevity we will use a labelling Scheme 1 whereby the complexes are referred to as: $\mathrm{RuL}^{2}-\mathrm{NdL}^{4}$ dinuclear complexes, bearing the alkoxysilyl group on bipyridine ruthenium moiety (i), and $\mathrm{RuL}^{1}-\mathrm{NdL}^{3}$ bearing the alkoxysilyl groups on the TTA lanthanide complex (ii). In both cases bipyrimidine is the bridging ligand on ruthenium center. Successful structural characterization of the silylated d-f heterobimetallic complexes is described and discussed in this work. Furthermore, photophysical properties of these heterobimetallic complexes are examined with respect to the efficiency of energy transfer processes from ruthenium(II) moieties to the luminescent NIR-emitting neodymium(III) ions.

\section{Experimental}

\section{Materials}

The silylating ligands, 4-methyl-4'-[methylamino3(propyltriethoxysilyl)]-2,2'-dipyridine (bpy-Si), and 4,4,4-trifluoro-2-(3-(trimethoxysilyl)-propyl)1-(2-thienyl)-1,3-butanedione (TTA-Si), were synthesized as previously described by Menu and co-workers. ${ }^{16,17}$ [cis$\left.\mathrm{RuCl}_{2}(\text { bpy })_{2}\right]$, (bpy = 2,2'-bipyridine), $\left[\mathrm{RuCl}_{2}\right.$ (bpy)(bpy$\mathrm{Si})]$ and $\left[\mathrm{Nd}(\mathrm{TTA})_{3}\right] \cdot 2 \mathrm{H}_{2} \mathrm{O}$ were synthesized as previously described. ${ }^{16,17}$ Thenoyltrifluoro-acetone (TTA), neodymium chloride anhydrous, ytterbium chloride anhydrous were purchased from Aldrich (Toulouse, France). 2,2'-Bipyrimidine were purchased from Acros (Toulouse, France). These reagents were used as received. Acetone, dichloromethane, diethylether, ethanol and pentane were purified by distillation in an inert atmosphere, degassed and dried using cryogenic and drying procedures, respectively. All manipulations concerning the preparation of ligands and complexes were performed in an inert atmosphere using the Schlenk tube technique.

\section{Characterization methods}

Fourier transform infrared (FTIR) spectra were obtained in the spectral range from 4000 to $650 \mathrm{~cm}^{-1}\left(4 \mathrm{~cm}^{-1}\right.$ of resolution) with a Bruker Vector 22 (KBr dispersion). The Raman spectra from all complexes were collected on a RFS 100 FT-Raman Bruker spectrometer equipped with a Ge detector using liquid nitrogen as the coolant and a Nd:YAG laser emitting at $1064 \mathrm{~nm}$. The laser light, with a power varying from 30 to $150 \mathrm{~mW}$, was introduced and focused on the sample, and the scattered radiation was collected at $180^{\circ}$. For each spectrum, an average of 1024 scans was performed at a resolution of $4 \mathrm{~cm}^{-1}$ over a range from 3500 to $50 \mathrm{~cm}^{-1}$. The OPUS 6.0 (Bruker Optik, Ettlingen, Germany) software was used for Raman data acquisition. For the lanthanide and heterobimetallic complexes, nuclear magnetic resonance (NMR) spectra were obtained using a 
(i)
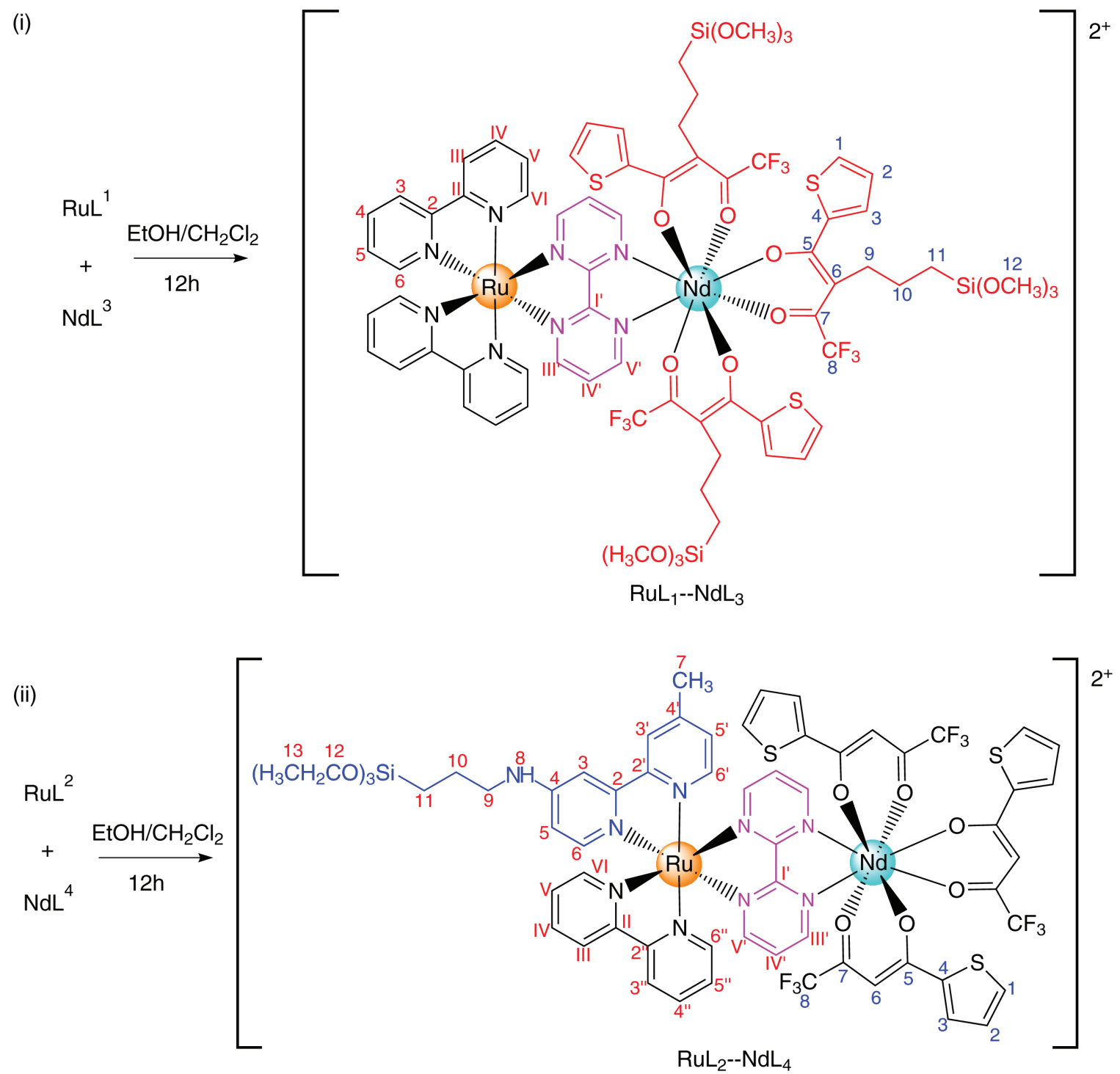

Scheme 1. Synthesis of the heterobimetallic complexes, $\mathrm{RuL}^{1}-\mathrm{NdL}^{3}(i)$ and $\mathrm{RuL}^{2}-\mathrm{NdL}^{4}($ ii). Numbering of the hydrogen and carbon atoms are identified as red and blue labels.

Bruker Advance $600 \mathrm{MHz}$ spectrometer at room temperature in deuterated solvents. Total correlation spectroscopy (TOCSY1D) spectra were recorded by selective irradiation of different aromatic hydrogen atoms of the complex with a selective pulse. The spectra were recorded after magnetization transfer at $120 \mathrm{~ms}$ of mixing time. ${ }^{1} \mathrm{H}\left\{{ }^{13} \mathrm{C}\right\}$ heteronuclear single quantum correlation (HSQC) NMR experiments were recorded using the spectral widths of 12000 and $24000 \mathrm{~Hz}$ for the ${ }^{1} \mathrm{H}$ and ${ }^{13} \mathrm{C}$ dimensions, respectively. The number of collected complex points was 1024 for the ${ }^{1} \mathrm{H}$ dimension with a recycle delay of $1.5 \mathrm{~s}$. The number of transients was from 24 to 48 depending of the sample and 128 time increments were recorded in the ${ }^{13} \mathrm{C}$ dimension. The ${ }^{1} J_{\mathrm{H}-\mathrm{C}}$ used was $145 \mathrm{~Hz}$. Prior to Fourier transformation, the data matrices were zero filled to 1024 points in the ${ }^{13} \mathrm{C}$ dimension. ${ }^{1} \mathrm{H}\left\{{ }^{13} \mathrm{C}\right\}$ heteronuclear multiple bond correlation (HMBC) NMR experiments were carried out using the spectral widths of 12000 and $24000 \mathrm{~Hz}$ for the ${ }^{1} \mathrm{H}$ and ${ }^{13} \mathrm{C}$ dimensions, respectively. The number of collected complex points was 1024 for the ${ }^{1} \mathrm{H}$ dimension with a recycle delay of $2.0 \mathrm{~s}$. The number of transients was from 16 to 32 depending of the sample and 128 time increments were recorded in the ${ }^{13} \mathrm{C}$ dimension. The ${ }^{3} J_{\mathrm{H}-\mathrm{C}}$ used was $8 \mathrm{~Hz}$. Prior to Fourier transformation, the data matrices were zero filled to 1024 points in the ${ }^{13} \mathrm{C}$ dimension. Data processing was performed using standard Bruker Topspin-NMR software. The central solvent line was used as an internal chemical shift reference point. Mass spectra (MS) were recorded using Q TOF 1er (Waters) spectrometer: source electrospray (ESI) or DSQ Thermo Fisher Scientific spectrometer equipped with chemical ionization source $\left(\mathrm{NH}_{3}\right)$. UV-Vis spectra were recorded 
using a Varian spectrophotometer model Cary 5000 in the region of 800 to $200 \mathrm{~nm}$ (resolution of $1 \mathrm{~nm}$ ) using Cary WinUV software. Elemental analyses of C, H, N and S were performed on a Carlo Erba instrument (EA 1110). Luminescence spectra were measured at room temperature using a Jobin-Yvon Model Fluorolog FL3-22 spectrometer equipped with a H10330-75 Hamamatsu detector, TE: cooled NIR-photomultiplier module and a $450 \mathrm{~W}$ Xe excitation lamp. Excitation and emission spectra were recorded under $\mathrm{CW}$ excitation and were corrected with respect to the Xe lamp intensity and spectrometer response. Fluorescence intensity decays were obtained using the time-correlated single-photon counting technique. The excitation source was a mode-locked Ti:saphire laser (Tsunami 3950 pumped by Millennia X Spectra Physics) producing 5 ps FWHM pulses ranging from 0.5 to $8.0 \mathrm{MHz}$ repetition rate, regulated by the 3980 Spectra Physics pulse picker. The laser was tuned to give output at $892 \mathrm{~nm}$ and a second harmonic generator BBO crystal (GWN-23PL Spectra Physics) gave the $448 \mathrm{~nm}$ excitation pulses that were directed to an Edinburgh FL900 spectrometer adjusted in L-format configuration. The emission wavelength of 620 and $670 \mathrm{~nm}$ were selected by a monochromator and emitted photons were detected by a cooled Hamamatsu R3809U microchannel plate photomultiplier. The whole instrument response function was typically $100 \mathrm{ps}$. Energy transfer rate constant $\left(\mathrm{k}_{\mathrm{EnT}}\right)$ and efficiency of energy transfer $\left(\eta_{\mathrm{EnT}}\right)$ were obtained using ruthenium ${ }^{3} \mathrm{MLCT}$ decay values from ruthenium precursors and the respective heterobimetallic complexes.

\section{Synthesis}

\section{$\left[\mathrm{Nd}(\mathrm{TTA}-\mathrm{Si})_{3}\right]\left(\mathrm{NdL}^{3}\right)$}

This complex was obtained by the procedure adapted from Duarte et al. ${ }^{17} 6 \mathrm{mmol}$ (2.30 g) of the TTA-Si and $2 \mathrm{mmol}(0.50 \mathrm{~g})$ of neodymium chloride anhydrous were added to $20 \mathrm{~mL}$ of anhydrous ethanol. The reaction mixture was kept under nitrogen atmosphere and stirred for $18 \mathrm{~h}$. The solvent was evaporated and the powder was then washed with pentane and diethylether, and dried under vacuum. The Nd(TTA-Si $)_{3}$ complex $\left(\mathrm{NdC}_{42} \mathrm{H}_{54} \mathrm{~F}_{9} \mathrm{O}_{15} \mathrm{~S}_{3} \mathrm{Si}_{3}\right.$, MW 1294.54) was obtained as a greenish powder (1.9 g, yield: 77\%). Elemental analysis found: C 38.45, H 3.5; calcd. for $\mathrm{NdC}_{41} \mathrm{H}_{52} \mathrm{O}_{15} \mathrm{~F}_{9} \mathrm{~S}_{3} \mathrm{Si}_{3}$ (one methoxy group hydrolyzed): C 38.45, H 4.1\%; UV (EtOH) $\lambda / \mathrm{nm} 267$ and 340; IR (KBr) $v / \mathrm{cm}^{-1} 3108 \mathrm{w}(v \mathrm{CH}), 2960 \mathrm{~m}$ and $2923 \mathrm{~m}\left(v_{\mathrm{as}} \mathrm{CH}_{2}, \mathrm{CH}_{3}\right), 2855 \mathrm{w}\left(v_{\mathrm{s}} \mathrm{CH}_{2}, \mathrm{CH}_{3}\right), 1609 \mathrm{vs}-\mathrm{br}$ $(v \mathrm{CO}), 1539 \mathrm{~s}$ and $1510 \mathrm{~m}(v \mathrm{CCO}), 1410 \mathrm{~s}$ and $1356 \mathrm{~s}$ $\left(v \mathrm{CCS}_{\text {thenoyl }}\right), 1304 \mathrm{vs}-\mathrm{br}\left(v \mathrm{CF}_{3}\right), 1060 \mathrm{~s}-\mathrm{br}\left(\nu \mathrm{SiOCH}_{3}\right), 788 \mathrm{~s}$ $\left(\delta \mathrm{CH}_{\text {thenoyl }}\right), 721 \mathrm{~m}\left(\delta \mathrm{CF}_{3}\right) ;{ }^{1} \mathrm{H}$ NMR $\left(600 \mathrm{MHz}, \mathrm{CDCl}_{3}\right)$ $\delta 0.83\left(2 \mathrm{H}, \mathrm{CH}_{2}, 11-\mathrm{H}\right), 1.90\left(2 \mathrm{H}, \mathrm{CH}_{2}, 10-\mathrm{H}\right), 3.57(2 \mathrm{H}$,
$\mathrm{CH}_{2}, 9-\mathrm{H}$ and $\left.9 \mathrm{H}, \mathrm{CH}_{3}, 12-\mathrm{H}\right), 7.19\left(1 \mathrm{H}, \mathrm{dd}, J_{\mathrm{H}-\mathrm{H}} 4.5\right.$ and $3.4 \mathrm{~Hz}, \mathrm{CH}, 2-\mathrm{H}), 7.75\left(1 \mathrm{H}, \mathrm{d}, J_{\mathrm{H}-\mathrm{H}} 4.9 \mathrm{~Hz}, \mathrm{CH}, 1-\mathrm{H}\right), 7.79$ $\left(1 \mathrm{H}, \mathrm{d}, J_{\mathrm{H}-\mathrm{H}} 3.4 \mathrm{~Hz}, \mathrm{CH}, 3-\mathrm{H}\right.$ ); MS (ESI) $\mathrm{m} / \mathrm{z}$, found for [(M- $\left.\mathrm{OCH}_{3}+\mathrm{OH}\right)-$ TTA-Si]: 895.9.

\section{$\left[\mathrm{Nd}(\mathrm{TTA})_{3}\left(\mathrm{H}_{2} \mathrm{O}\right)_{2}\right]\left(\mathrm{NdL}^{4}\right)$}

This complex was obtained by the procedure described by Duarte et al. ${ }^{17} 3 \mathrm{mmol}(0.666 \mathrm{~g})$ of TTA were added to $30 \mathrm{~mL}$ of ethanol. Then $450 \mu \mathrm{L}$ of $\mathrm{NH}_{4} \mathrm{OH}$ were added. $1 \mathrm{mmol}(0.279 \mathrm{~g})$ of neodymium chloride were dissolved in $30 \mathrm{~mL}$ of water and added to the previous solution. The reaction mixture was kept under stirring for $3 \mathrm{~h}$. The obtained powder was recovered and dissolved in acetone; then it was re-crystalized by precipitation on cold water and dried under vacuum. The $\left[\mathrm{Nd}(\mathrm{TTA})_{3} \mathrm{H}_{2} \mathrm{O}_{2}\right]$ complex $\left(\mathrm{NdC}_{24} \mathrm{H}_{16} \mathrm{O}_{8} \mathrm{~F}_{9} \mathrm{~S}_{3}, \mathrm{MW}\right.$ 843.80) was obtained as a yellow powder $(0.59 \mathrm{~g}$, yield: $70 \%)$. Elemental analysis found: C 34.1, H 1.5; calcd. for $\mathrm{NdC}_{24} \mathrm{H}_{16} \mathrm{O}_{8} \mathrm{~F}_{9} \mathrm{~S}_{3}: \mathrm{C} 34.1, \mathrm{H} 1.9 \%$; $\mathrm{UV}(\mathrm{EtOH}) \lambda / \mathrm{nm} 268$ and 340; IR (KBr) $v / \mathrm{cm}^{-1} 3330 \mathrm{~m}-\mathrm{br}$ $(v \mathrm{OH}), 3115(v \mathrm{CH}), 1606 v \mathrm{~s}(\nu \mathrm{CO}), 1542 \mathrm{~s}$ and $1514 \mathrm{~s}$ $(v \mathrm{CCO}), 1411 \mathrm{~s}$ and $1358 \mathrm{~s}\left(v \mathrm{CCS}_{\text {thenoyl }}\right), 1300 v \mathrm{vs}-\mathrm{br}\left(v_{\mathrm{CF}}\right)$, $789 \mathrm{w}\left(\delta \mathrm{CH}_{\text {thenoyl }}\right), 716 \mathrm{w}\left(\delta \mathrm{CF}_{3}\right)$; MS (desorption chemical ionization, DCI, $\mathrm{NH}_{3}$ ) $\mathrm{m} / z$, found for $\left[\mathrm{M}+\mathrm{H}^{+}-2 \mathrm{H}_{2} \mathrm{O}\right]$ : 807.8; $\left[\mathrm{M}+\mathrm{H}^{+}-\mathrm{H}_{2} \mathrm{O}\right]$ : 825.8.

\section{$\left[\mathrm{Ru}(\mathrm{bpy})_{2}(\mathrm{bpmd})\right] \mathrm{Cl}_{2}\left(\mathrm{RuL}^{1}\right)$}

$1.88 \mathrm{mmol}(0.307 \mathrm{~g})$ of 2,2'-bipyrimidine and $1.71 \mathrm{mmol}(0.830 \mathrm{~g})$ of $\left[c i s-\mathrm{RuCl}_{2}(\mathrm{bpy})_{2}\right]$, were added to $40 \mathrm{~mL}$ of anhydrous and degassed ethanol. The reaction mixture was kept under nitrogen atmosphere and refluxing at $78{ }^{\circ} \mathrm{C}$ for $72 \mathrm{~h}$. The solvent was evaporated, and the powder was then washed with pentane and diethyl ether, and dried under vacuum. The $\left[\mathrm{Ru}(\mathrm{bpy})_{2}(\mathrm{bpmd})\right] \mathrm{Cl}_{2}$ complex $\left(\mathrm{RuC}_{28} \mathrm{H}_{22} \mathrm{~N}_{8} \mathrm{Cl}_{2}\right.$, MW 642.50) was obtained as a brown powder $(1.1 \mathrm{~g}$, yield: $85 \%)$. Elemental analysis found: C 49.7, H 3.4, N 16.8; calcd. for $\mathrm{RuC}_{28} \mathrm{H}_{22} \mathrm{~N}_{8} \mathrm{Cl}_{2} \cdot \mathrm{H}_{2} \mathrm{O}$ : C 52.3, H 3.45, N 17.4\%; UV (EtOH) $\lambda / \mathrm{nm} 245,286$ and 424 ; IR (KBr) $v / \mathrm{cm}^{-1} 3064 \mathrm{w}(v \mathrm{CH}), 1630 \mathrm{~m}-b r$ and $1601 \mathrm{~s}$ $(v \mathrm{CN}), 1572 \mathrm{~s}, 1463 \mathrm{~s}, 1443 \mathrm{~s} 1420 \mathrm{~m}$ and $1400 \mathrm{vs}(\nu \mathrm{CC})$, $772 \mathrm{vs}\left(\delta \mathrm{CH}_{\mathrm{ar}}\right)$; MS (ESI) $\mathrm{m} / z$, found for $\left[\mathrm{M}^{2+} / 2\right]$ : 286.1 .

\section{$[\mathrm{Ru}(\mathrm{bpy})(\mathrm{bpy}-\mathrm{Si})(\mathrm{bpmd})] \mathrm{Cl}_{2}\left(\mathrm{RuL}^{2}\right)$}

$1.38 \mathrm{mmol}(0.225 \mathrm{~g})$ of 2,2'-bipyrimidine and $1.38 \mathrm{mmol}(1.01 \mathrm{~g})$ of $\left[\mathrm{RuCl}_{2}\right.$ (bpy)(bpy-Si)] were added to $40 \mathrm{~mL}$ of anhydrous and degassed ethanol. The reaction mixture was kept under nitrogen atmosphere and refluxing at $78{ }^{\circ} \mathrm{C}$ for $72 \mathrm{~h}$. The solvent was evaporated, and the powder was washed with diethyl ether, and dried under vacuum. The $[\mathrm{Ru}(\mathrm{bpy})(\mathrm{bpy}-\mathrm{Si})(\mathrm{bpmd})] \mathrm{Cl}_{2}$ complex $\left(\mathrm{RuC}_{39} \mathrm{H}_{47} \mathrm{~N}_{9} \mathrm{O}_{3} \mathrm{SiCl}_{2}\right.$, MW 889.91) was obtained as a black powder (0.98 g, yield: $80 \%)$. Elemental analysis found: 
C 50.0, H 4.9, N 13.65; calcd. for $\mathrm{RuC}_{39} \mathrm{H}_{47} \mathrm{~N}_{9} \mathrm{O}_{3} \mathrm{SiCl}_{2}$ : C 52.6, H 5.3, N 14.1\%; UV (EtOH) $\lambda / \mathrm{nm} \mathrm{250,} 287$ and 443; IR (KBr) $v / \mathrm{cm}^{-1} 3064 \mathrm{w}(v \mathrm{CH}), 2967 \mathrm{w}$ and $2923 \mathrm{w}$ $\left(v_{\text {as }} \mathrm{CH}_{2}, \mathrm{CH}_{3}\right), 2867 \mathrm{w}\left(v_{\mathrm{s}} \mathrm{CH}_{2}, \mathrm{CH}_{3}\right), 1637 \mathrm{sh}$ and $1618 \mathrm{~s}$ $(\nu \mathrm{CN}), 1553 \mathrm{~s}, 1464 \mathrm{~m}, 1444 \mathrm{~m}, 1421 \mathrm{~m}$ and $1400 \mathrm{vs}(\nu \mathrm{CC})$, $1072 \mathrm{~s}-\mathrm{br}(v \mathrm{SiOC}), 771 \mathrm{~s}\left(\delta \mathrm{CH}_{\mathrm{ar}}\right)$; MS (ESI) $m / z$, found for $\left[\mathrm{M}^{2+} / 2\right]: 409.4$.

\section{$\left[\mathrm{Ru}(\mathrm{bpy})_{2}(\mathrm{bpmd}) \mathrm{Nd}(\mathrm{TTA}-\mathrm{Si})_{3} \mathrm{Cl}_{2}\left(\mathrm{RuL}^{1}-\mathrm{NdL}^{3}\right)\right.$}

$0.33 \mathrm{mmol}(0.208 \mathrm{~g})$ of the $\left[\mathrm{Ru}(\mathrm{bpy})_{2}(\mathrm{bpmd})\right] \mathrm{Cl}_{2}\left(\mathrm{RuL}^{1}\right)$ was added to $10 \mathrm{~mL}$ of anhydrous and degassed ethanol and then $0.33 \mathrm{mmol}(0.420 \mathrm{~g})$ of $\mathrm{Nd}(\mathrm{TTA}-\mathrm{Si})_{3}\left(\mathrm{NdL}^{3}\right)$ diluted in $10 \mathrm{~mL}$ of anhydrous and degassed dichlorometane were added to the first solution. The reaction mixture was kept under nitrogen atmosphere for $12 \mathrm{~h}$ at room temperature. The solvent was half evaporated and filtered. The obtained powder was washed with pentane and diethyl ether, and dried under vacuum. The $\left[\mathrm{Ru}(\mathrm{bpy})_{2}(\right.$ bpmd $\left.) \mathrm{Nd}(\mathrm{TTA}-\mathrm{Si})_{3}\right] \mathrm{Cl}_{2}$ complex $\left(\mathrm{C}_{70} \mathrm{H}_{76} \mathrm{~N}_{8} \mathrm{O}_{15} \mathrm{~F}_{9} \mathrm{~S}_{3} \mathrm{Si}_{3} \mathrm{RuNdCl}{ }_{2}\right.$, MW: 1937.05) was obtained as a dark brown powder $(0.35 \mathrm{~g}$, yield: 55\%). Elemental analysis found: C 41.4, H 2.95, N 5.8, S 5.1; calcd. for $\mathrm{C}_{70} \mathrm{H}_{76} \mathrm{~N}_{8} \mathrm{O}_{15} \mathrm{~F}_{9} \mathrm{~S}_{3} \mathrm{Si}_{3} \mathrm{RuNdCl}_{2}$ : C 43.4, H 3.95, N 5.8, S 5.0\%; UV (EtOH) $\lambda / \mathrm{nm} 257,270,285$, 339 and 423; IR (KBr) $v / \mathrm{cm}^{-1} 3070 \mathrm{w}(\nu \mathrm{CH}), 2972 \mathrm{w}$ $\left(v_{\mathrm{as}} \mathrm{CH}_{2}, \mathrm{CH}_{3}\right), 1631 \mathrm{sh}$ and $1605 \mathrm{vs}(\mathrm{vCN}), 1535 \mathrm{~s}$ and $1508 \mathrm{~m}$ ( $v$ CCO $), 1576 \mathrm{w}, 1463 \mathrm{~m}$ and $1446 \mathrm{~m}(v \mathrm{CC}), 1411 \mathrm{~s}-\mathrm{br}$ and $1354 \mathrm{~m}\left(v \mathrm{CCS}_{\text {thenoyl }}\right), 1302 \mathrm{vs}\left(v \mathrm{CF}_{3}\right), 1060 \mathrm{w}\left(v \mathrm{SiOCH}_{3}\right)$, $785 \mathrm{w}\left(\delta \mathrm{CH}_{\text {thenoyl }}\right), 767 \mathrm{w}\left(\delta \mathrm{CH}_{\text {ar }}\right), 728 \mathrm{w}\left(\delta \mathrm{CF}_{3}\right) ;{ }^{1} \mathrm{H} \mathrm{NMR}$ $\left(600 \mathrm{MHz}, \mathrm{CDCl}_{3}\right) \delta 0.85$ (br s, $\mathrm{CH}_{2}, 11-\mathrm{H}$ ), 1.91 (br s, $\mathrm{CH}_{2}, 10-\mathrm{H}$ ), 3.59 (br s, $\mathrm{CH}_{2}, 9-\mathrm{H}$ and br s, $\mathrm{CH}_{3}, 12-\mathrm{H}$ ), 7.15 (br s, CH, IV'-H), 7.18 (dd, $\left.J_{\mathrm{H}-\mathrm{H}} 6.2 \mathrm{~Hz}, \mathrm{~V}-\mathrm{H}\right), 7.29$ (dd, $\left.J_{\mathrm{H}-\mathrm{H}} 6.4 \mathrm{~Hz}, \mathrm{CH}, 5-\mathrm{H}\right), 7.38\left(\mathrm{~d}, J_{\mathrm{H}-\mathrm{H}} 4.9 \mathrm{~Hz}, \mathrm{VI}-\mathrm{H}\right), 7.53(\mathrm{br}$ s, CH, 2-H), 7.55 (br s, CH, 6-H), 7.65 (br s, CH, V'-H), $7.70\left(\mathrm{dd}, J_{\mathrm{H}-\mathrm{H}} 6.2 \mathrm{~Hz}, \mathrm{CH}, \mathrm{IV}-\mathrm{H}\right), 7.80\left(\mathrm{dd}, J_{\mathrm{H}-\mathrm{H}} 7.7 \mathrm{~Hz}, \mathrm{CH}\right.$, 4-H), $7.97\left(\mathrm{~d}, J_{\mathrm{H}-\mathrm{H}} 3.8 \mathrm{~Hz}, \mathrm{CH}, 1-\mathrm{H}\right), 8.15\left(\mathrm{~d}, J_{\mathrm{H}-\mathrm{H}} 5.9 \mathrm{~Hz}\right.$, CH, III-H), 8.19 (d, $\left.J_{\mathrm{H}-\mathrm{H}} 7.4 \mathrm{~Hz}, \mathrm{CH}, 3-\mathrm{H}\right), 8.72$ (br s, CH, III'-H), 9.08 (br s, CH, 3-H); MS (ESI) $m / z$, found for $\left.\left[\mathrm{Ru}(\mathrm{bpy})_{2}(\mathrm{bpmd})\right]^{2+} / 2\right]$ : 286.1; [M - TTA-Si]: 1551.0.

$\left[\mathrm{Nd}(\mathrm{TTA})_{3}(\mathrm{bpmd}) \mathrm{Ru}(\mathrm{bpy})(\mathrm{bpy}-\mathrm{Si})\right] \mathrm{Cl}_{2}\left(\mathrm{RuL}^{2}-\mathrm{NdL}^{4}\right)$

$0.28 \mathrm{mmol}(0.250 \mathrm{~g})$ of the $[\mathrm{Ru}(\mathrm{bpy})(\mathrm{bpy}-\mathrm{Si})(\mathrm{bpmd})] \mathrm{Cl}_{2}$ $\left(\mathrm{RuL}^{2}\right)$ was added to $10 \mathrm{~mL}$ of anhydrous and degassed ethanol and then $0.28 \mathrm{mmol}(0.240 \mathrm{~g})$ of $\left[\mathrm{Nd}(\mathrm{TTA})_{3}\left(\mathrm{H}_{2} \mathrm{O}\right)_{2}\right]$, $\left(\mathrm{NdL}^{4}\right)$ diluted in $10 \mathrm{~mL}$ of anhydrous and degassed dichloromethane were added to the ruthenium solution. The reaction mixture was kept under nitrogen atmosphere for $12 \mathrm{~h}$ at room temperature. The solvent was half evaporated and filtered. The obtained powder was washed with pentane and diethyl ether, and dried under vacuum. The [Ru(bpy)(bpy-Si) (bpmd) $\left.\mathrm{Nd}(\mathrm{TTA})_{3}\right] \mathrm{Cl}_{2}$ complex $\left(\mathrm{C}_{63} \mathrm{H}_{59} \mathrm{~N}_{9} \mathrm{O}_{9} \mathrm{~F}_{9} \mathrm{~S}_{3} \mathrm{SiRuNdCl}{ }_{2}\right.$, MW 1697.68) was obtained as a black powder $(0.26 \mathrm{~g}$, yield:
55\%). Elemental analysis found: C 44.15, H 3.5, N 7.6; calcd. for $\mathrm{C}_{63} \mathrm{H}_{59} \mathrm{~N}_{9} \mathrm{O}_{9} \mathrm{~F}_{9} \mathrm{~S}_{3} \mathrm{SiRuNdCl}_{2}$ : C 44.6, H 3.7, N 7.4\%; UV (EtOH) $\lambda / \mathrm{nm} \mathrm{258,} \mathrm{287,} 339$ and 437; IR (KBr) $v / \mathrm{cm}^{-1}$ $3069 \mathrm{w}(v \mathrm{CH}), 2978 \mathrm{w}$ and $2923 \mathrm{w}\left(v_{\mathrm{as}} \mathrm{CH}_{2}, \mathrm{CH}_{3}\right), 1634 \mathrm{sh}$ and $1609 \mathrm{vs}(v \mathrm{CN}), 1555 \mathrm{~s}$ and $1506 \mathrm{~m}(v \mathrm{CCO}), 1575 \mathrm{w}$, $1465 \mathrm{~m}$ and $1446 \mathrm{~m}(v \mathrm{CC}), 1413 \mathrm{~s}$, and $1355 \mathrm{~m}\left(v \mathrm{CCS}_{\text {thenoyy }}\right)$, $1302 v s-b r\left(v \mathrm{CF}_{3}\right), 1076 \mathrm{w}$ ( $\left.v \mathrm{SiOC}\right), 783 \mathrm{~m}\left(\mathrm{CH}_{\text {thenoyl }}\right), 767 \mathrm{w}$ $\left(\delta \mathrm{CH}_{\mathrm{ar}}\right), 717 \mathrm{w}\left(\delta \mathrm{CF}_{3}\right) ; \mathrm{MS}(\mathrm{ESI}) \mathrm{m} / \mathrm{z}$, found for $\left[\mathrm{M}^{+}-\mathrm{Cl}\right]$ : 1662.2.

\section{Results and Discussion}

Synthesis and structural characterization of silylated ruthenium(II)-neodymium(III) heterobinetallic complexes

The synthesis routes of three new mononuclear complexes denoted by (i) $\mathrm{RuL}^{1}$, (ii) $\mathrm{RuL}^{2}$ and (iii) $\mathrm{NdL}^{3}$ has been achieved in Supplementary Information (SI) section (Figure S1). Equimolar reaction of ruthenium complex bearing the bridging ligand, $\mathrm{RuL}^{1}$, with silylated tris(diketonate) neodymium complex, $\mathrm{NdL}^{3}$, gives rise to $\mathrm{RuL}^{1}-\mathrm{NdL}^{3}$ heterobimetallic complex (i, Scheme 1). On the other hand, the combination of $\mathrm{RuL}^{2}$ complex, containing both silyl and bridging groups, with tris(diketonate) neodymium complex, $\mathrm{Nd}(\mathrm{TTA})_{3}$ denoted by $\mathrm{NdL}^{4}$ (synthesis route and structure of $\mathrm{NdL}^{4}$ were done in Figure S2, SI section), leads to heterobimetallic $\mathrm{RuL}^{2}-\mathrm{NdL}^{4}$ complex with the trialkoxysilyl functional group on the ruthenium moiety (ii, Scheme 1).

FTIR spectra (Figure 1) exhibit indicative bands for lanthanide units in $\mathrm{NdL}^{3}, \mathrm{NdL}^{4}$ and both heterobimetallic complexes with the stronger vibration bands in the range $1603-1610\left(v_{\mathrm{C}=0}\right), 1539-1543\left(v_{\mathrm{C}-\mathrm{C}-\mathrm{O}}\right), 1411-1412\left(v_{\mathrm{CS} \text { thienyy }}\right)$, $1300-1310 \mathrm{~cm}^{-1}\left(v_{\mathrm{CF} 3}\right)$ related to diketonate ligands. Concerning the $\mathrm{NdL}^{3}$ and $\mathrm{RuL}^{1}-\mathrm{NdL}^{3}$ complexes (Figure 1a red and blue lines, respectively), the presence of bands at $1060\left(v_{\mathrm{Si}-\mathrm{O}-\mathrm{CH} 3}\right)$ suggests the successful synthesis of both methoxysilyl complexes. These results are in agreement with EA and MS (molecular peaks for $\mathrm{RuL}^{1}$ and $\mathrm{RuL}^{1}-\mathrm{NdL}^{3}$ at $m / z=286.1\left[\mathrm{M}^{2+} / 2\right]$ and $\left.286.1\left[\mathrm{Ru}(\mathrm{bpy})_{2}(\mathrm{bpmd})\right]^{2+} / 2\right]$; 1551.0 [M - TTA-Si], respectively).

For $\mathrm{RuL}^{2}$ and $\mathrm{RuL}^{2}-\mathrm{NdL}^{4}$ complexes (Figure $1 \mathrm{~b}$ red and blue lines, respectively), three bands 1072 and $1076 \mathrm{~cm}^{-1}$ $\left(v_{\text {Si-O-C }}\right)$, respectively confirming that the reaction was performed avoiding the hydrolysis and self-polymerization of the ethoxysilyl groups. These results are in agreement with EA and MS (molecular peaks for $\mathrm{RuL}^{2}$ and $\mathrm{RuL}^{2}-\mathrm{NdL}^{4}$ at $m / z=409.4\left[\mathrm{M}^{2+} / 2\right]$ and $1662.2\left[\mathrm{M}^{+}-\mathrm{Cl}\right]$, respectively). The $\mathrm{NdL}^{4}$ complex (Figure 1b, red line) was successfully prepared and characterized as already described in the Experimental section. 

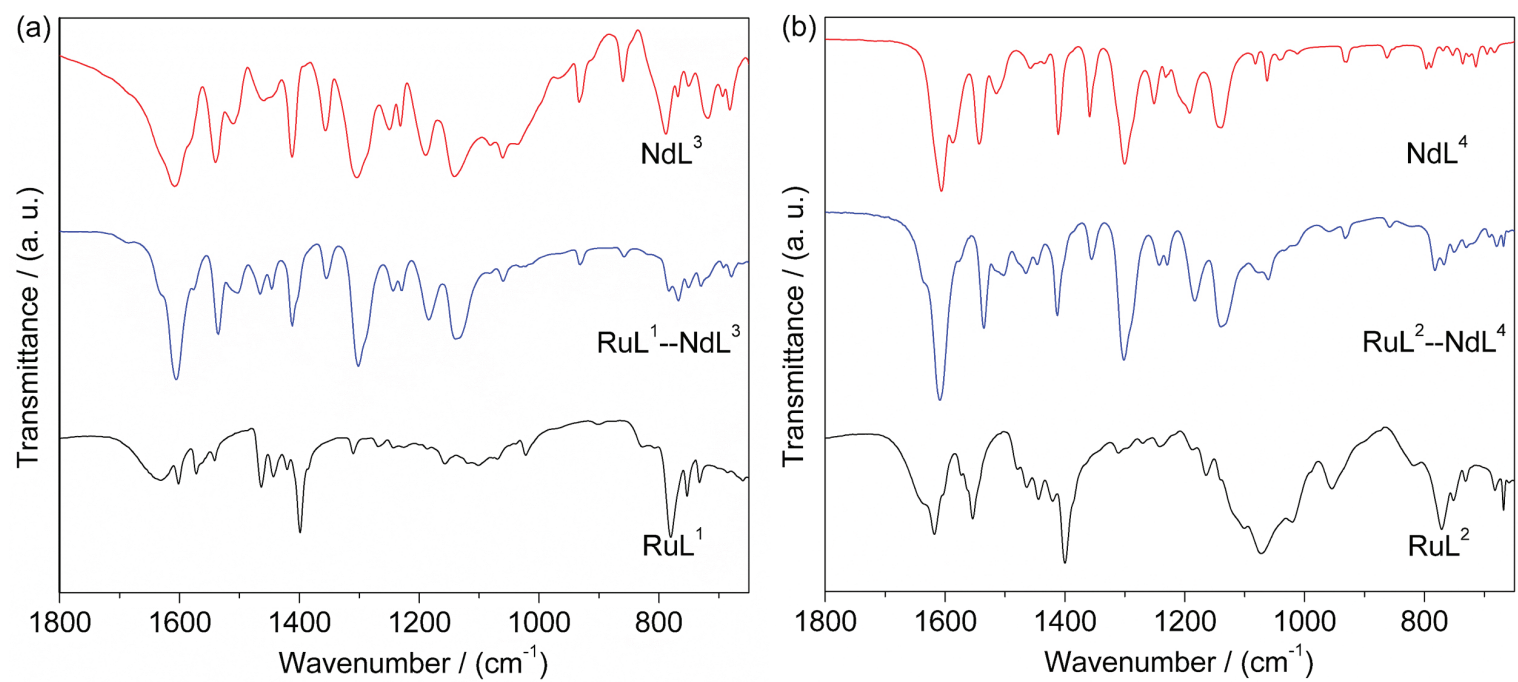

Figure 1. FTIR spectra for the (a) $\mathrm{NdL}^{3}, \mathrm{RuL}^{1}-\mathrm{NdL}^{3}$ and $\mathrm{RuL}^{1}$; (b) $\mathrm{NdL}^{4}, \mathrm{RuL}^{2}-\mathrm{NdL}^{4}$ and $\mathrm{RuL}^{2}$ complexes. All analyses were carried out as $\mathrm{KBr}$ pellets.

Raman spectroscopy allows accurate assignment of $\mathrm{CCH}$ stretching vibration bands at 1028, 1040, 1202, 1490 and $1580 \mathrm{~cm}^{-1}$ of heterocycles of the bpy and bpmd ligands of ruthenium units in $\mathrm{RuL}^{1}-\mathrm{NdL}^{3}$ and $\mathrm{RuL}^{2}-\mathrm{NdL}^{4}$ heterobimetallic complexes. The ruthenium(II) coordination was confirmed by the band observed at $1030 \mathrm{~cm}^{-1}\left(v_{\mathrm{Ru}-\mathrm{N}}\right) \cdot{ }^{23,24}$ Both spectroscopies appeared well complement one another. Raman scattering spectra are shown in Figure S3 (SI section).

The steric arrangement of the ligands in the metal coordination sphere in $\mathrm{NdL}^{3}$ and $\mathrm{RuL}^{1}-\mathrm{NdL}^{3}$ complexes have been elucidated by assignment of chemical shifts, $J_{\mathrm{H}-\mathrm{C}}$ and $J_{\mathrm{H}-\mathrm{H}}$ coupling constant and using complementary NMR studies such as TOCSY1D, ${ }^{1} \mathrm{H}\left\{{ }^{13} \mathrm{C}\right\}$-HSQC and ${ }^{1} \mathrm{H}\left\{{ }^{13} \mathrm{C}\right\}$-HMBC experiments (Figures $\mathrm{S} 4$, $\mathrm{S} 5$ for $\mathrm{NdL}^{3}$ and S6-S9 for $\mathrm{RuL}^{1}-\mathrm{NdL}^{3}$, SI section). Numbering of the hydrogen and carbon atoms used in the further characterization is detailed in Figure S1 (SI section) and Scheme 1 for each complexes. Most probable because of the presence of the silyl group, compounds behave as hygroscopic powders and all attempts to grow single crystals have been unsuccessful.

\section{Photophysical properties}

Figure 2 shows the UV-Vis absorption spectra for the two types of heterobimetallic complexes and respective precursors. Figure 2a black line, shows the spectrum obtained for the RuL ${ }^{1}$ complex. Strong and broad bands are observed at 245 and $424 \mathrm{~nm}$ attributed to $\mathrm{d} \rightarrow \pi^{*}{ }^{1}$ MLCT transitions ( $\mathrm{RuL}^{1}$ to bpy and bpmd ligands, respectively) and a strong and sharp band at $286 \mathrm{~nm}$ attributed to $\mathrm{p} \rightarrow \pi^{*}$ transitions of bpy and bpmd ligands. ${ }^{25}$ For $\mathrm{NdL}^{3}$ complex (Figure 2a, red line), the absorption bands at 269 and
$340 \mathrm{~nm}$ were assigned to singlet-to-singlet transitions in the TTA-Si ligands. ${ }^{17}$ The spectrum obtained for $\mathrm{RuL}^{1}-\mathrm{NdL}^{3}$ complex (Figure 2a, blue line) shows the strong and broad absorption bands at 257, 285 and $423 \mathrm{~nm}$, attributed to the $\pi \rightarrow \pi^{*}$ transitions of the ligands coordinated to the ruthenium center and $\mathrm{d} \rightarrow \pi^{*}{ }^{1}$ MLCT transitions from the ruthenium center to bpy and bpmd ligands. The absorption bands at 270 and $339 \mathrm{~nm}$ are ascribed to singlet-to-singlet ligands transitions present in the neodymium(III) center. Concerning the RuL ${ }^{2}$ complex, the bpy-Si was confirmed by bands at 250 and $443 \mathrm{~nm}$, attributed to $\mathrm{d} \rightarrow \pi^{*}{ }^{1} \mathrm{MLCT}$ transitions from the ruthenium(II) center to bpy-Si and bpmd ligands (Figure 2b, black line) and a strong and sharp band at $287 \mathrm{~nm}$ attributed to $\pi \rightarrow \pi^{*}$ transitions of bpy-Si and bpmd ligands. Comparing spectra obtained for $\mathrm{RuL}^{1}$ and $\mathrm{RuL}^{2}$ one may note a red shift of around $20 \mathrm{~nm}$ for ${ }^{1}$ MLCT state with the addition of the silylated ligand. The spectrum obtained for $\mathrm{NdL}^{4}$ complex (Figure 2b, red line) displays two bands at 268 and $340 \mathrm{~nm}$ assigned to singlet-to-singlet transitions in the TTA ligands. ${ }^{17}$ The spectrum of $\mathrm{RuL}^{2}-\mathrm{NdL}^{4}$ complex (Figure $2 b$, blue line) displays strong and broad absorption bands at 258, 287 and $437 \mathrm{~nm}$, characteristic of $\pi \rightarrow \pi^{*}$ transitions of the ligands coordinated to the ruthenium center and $\mathrm{d} \rightarrow \pi^{*}{ }^{1} \mathrm{MLCT}$ transitions from the ruthenium to bpy-Si and bpmd ligands. The absorption bands at 258 to $339 \mathrm{~nm}$ are assigned to the singlet-to-singlet ligands transitions present in the neodymium(III) complex.

The characteristic infrared emission from the lanthanide counterpart is observed when excitation is set in the visible at the MLCT ruthenium(II) band (at $450 \mathrm{~nm}$ ). For $\mathrm{RuL}^{1}-\mathrm{NdL}^{3}$, neodymium(III) ${ }^{4} \mathrm{~F}_{3 / 2} \rightarrow{ }^{4} \mathrm{I}_{1 / 2}$ and ${ }^{4} \mathrm{~F}_{3 / 2} \rightarrow{ }^{4} \mathrm{I}_{13 / 2}$ transitions at 1065 (sharp band) and $1334 \mathrm{~nm}$ (low intensity band) were detected as depicted in Figure 3a blue line. ${ }^{925,26}$ 

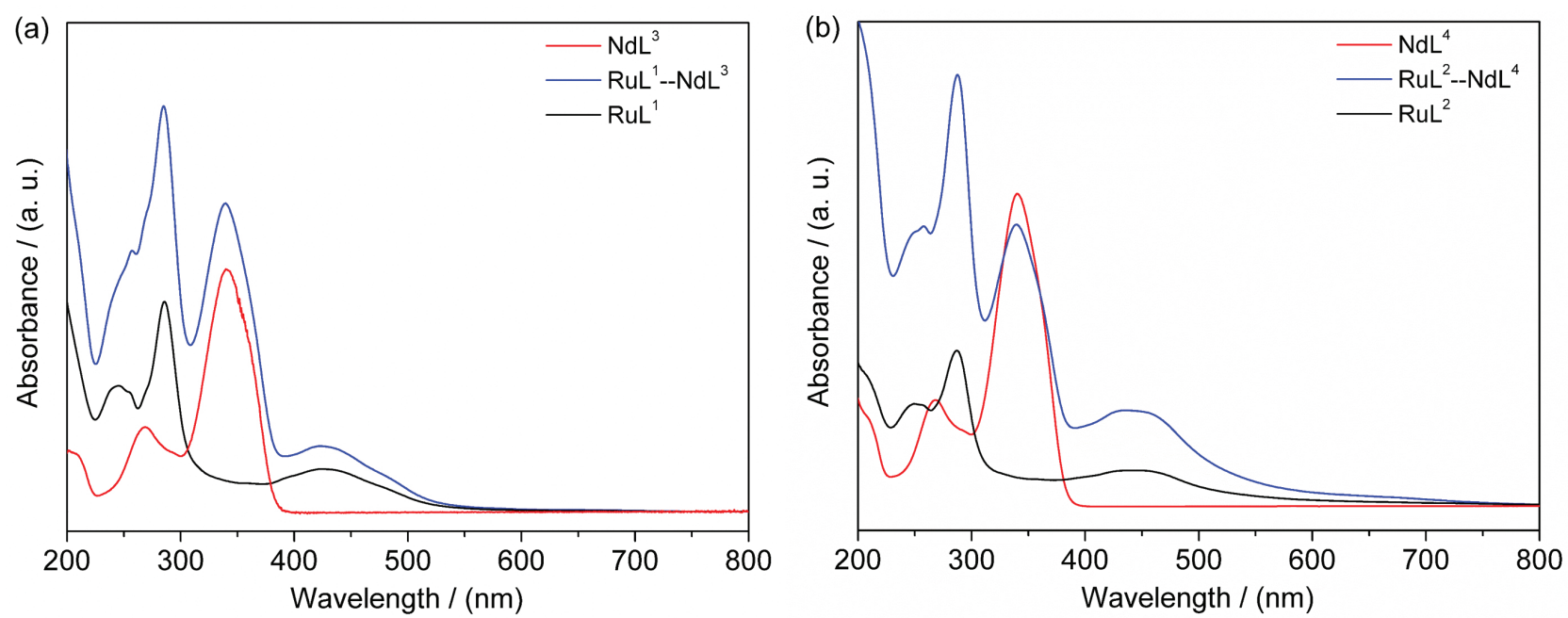

Figure 2. Absorption spectra $\left(2.5 \times 10^{-5} \mathrm{~mol} \mathrm{~L}^{-1}\right.$, ethanol) of (a) $\mathrm{NdL}^{3}$ (red line), $\mathrm{RuL}^{1}-\mathrm{NdL}^{3}$ (blue line), $\mathrm{RuL}^{1}$ (black line) and (b) $\mathrm{NdL}^{4}$ (red line), $\mathrm{RuL}^{2}-\mathrm{NdL}^{4}$ (blue line), $\mathrm{RuL}^{2}$ (black line).

The $\mathrm{RuL}^{2}-\mathrm{NdL}^{4}$ (Figure 3b, blue line) displayed similar transitions bands at $1066\left({ }^{4} \mathrm{~F}_{3 / 2} \rightarrow{ }^{4} \mathrm{I}_{11 / 2}\right)$ and $1334 \mathrm{~nm}$ $\left({ }^{4} \mathrm{~F}_{3 / 2} \rightarrow{ }^{4} \mathrm{I}_{13 / 2}\right)$, respectively. ${ }^{9,25,26}$ Excitation spectra obtained by monitoring the NIR emission ( $\lambda_{\text {em }}: 1065$ and $1066 \mathrm{~nm}$ for $\mathrm{RuL}^{1}-\mathrm{NdL}^{3}$ and $\mathrm{RuL}^{2}-\mathrm{NdL}^{4}$, respectively) are also shown in Figures 3a-3b, red lines. For both heterobimetallic complexes, three sharp bands were detected in visible range and ascribed to neodymium(III) intraconfigurational f-f transitions at 581, 746 and $800 \mathrm{~nm} \cdot{ }^{9,26}$ The broad band from 270 to $400 \mathrm{~nm}$ were assigned to transitions centered at TTA-Si, bpy and bpmd ligands. . $^{14,17,18,26}$ Bands ranging from 400 to $600 \mathrm{~nm}$ were attributed to the ruthenium(II) ${ }^{3}$ MLCT transition. ${ }^{25}$ Further information on the energy transfer from the ruthenium counterpart to the lanthanide one is these heterobimetallic compounds can be obtained by analyzing the changes observed for the Ru visible emission properties (Figures S10 and S11, SI section).

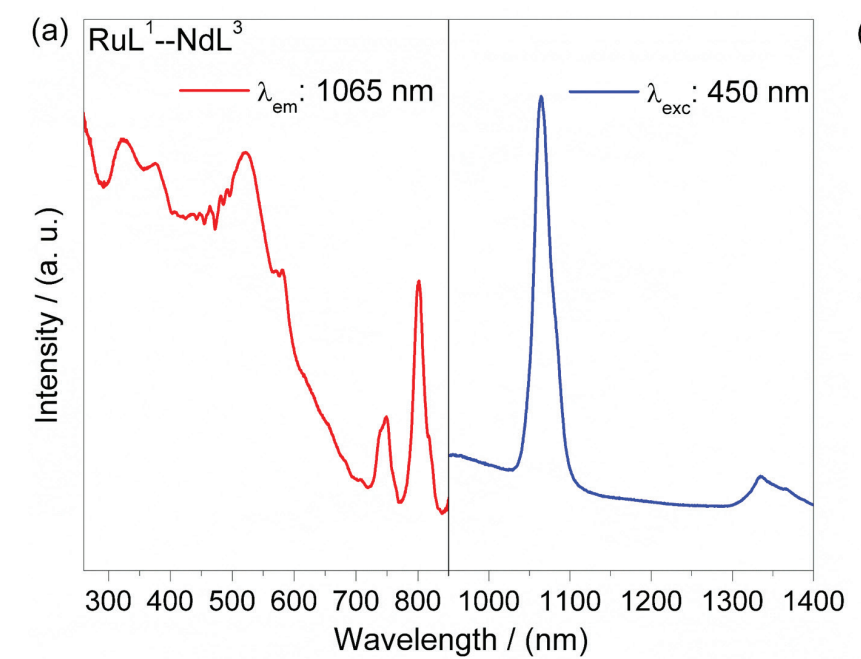

Table 1 shows results for excited state lifetimes. Considering bpmd as a planar bridging ligand that provides short metal-metal distance and a pathway that favors efficient energy transfer in heterobimetallic complexes, especially for neodymium(III) and ytterbium(III) ions, ${ }^{10}$ the lifetime values obtained for $\mathrm{RuL}^{1}$ and $\mathrm{RuL}^{2}$ substantially reduced in $\mathrm{RuL}^{1}-\mathrm{NdL}^{3}$ and $\mathrm{RuL}^{2}-\mathrm{NdL}^{4}$ complexes suggesting energy transfer processes for both heterobimetallic complexes. The $\mathrm{k}_{\mathrm{EnT}}$ and $\eta_{\mathrm{EnT}}$ may be evaluated from lifetimes as shown in Table 1.

A pathway of energy transfer (EnT) is presented in Scheme 2. The proposed energy level diagram suggests that the $\mathrm{RuL}^{2}$ and $\mathrm{RuL}^{1}{ }^{3} \mathrm{MLCT}$ energy are suitable for the sensitization of the neodymium(III) luminescence. The RuL ${ }^{2}$ complex ${ }^{3}$ MLCT energy level is centered at $16129 \mathrm{~cm}^{-1}$ and the energy transfer to neodymium(III) could be evaluated. Considering the $\mathrm{RuL}^{2}-\mathrm{NdL}^{4}$ complex,

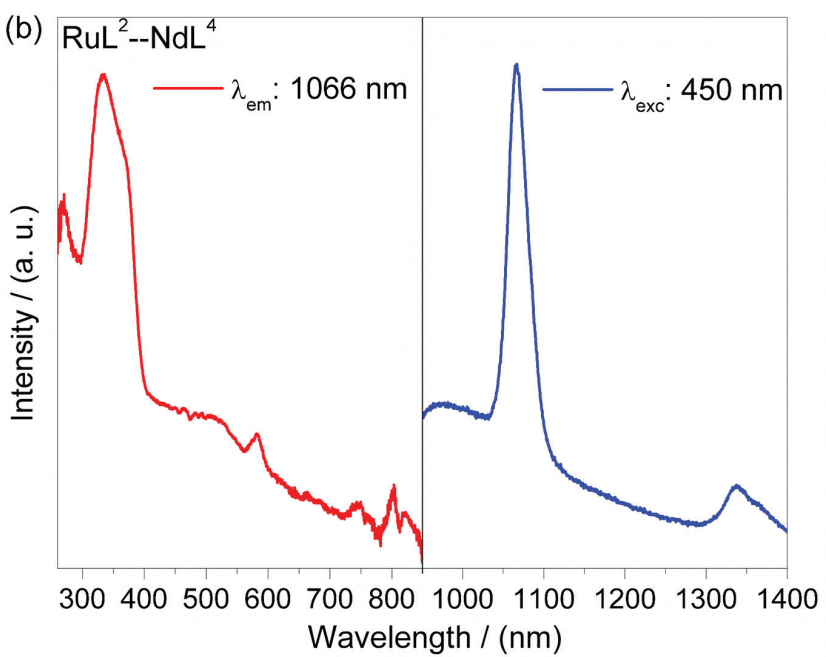

Figure 3. Room temperature excitation (red lines) and emission (blue lines) spectra from (a) $\mathbf{R u L} \mathbf{L}^{1}-\mathbf{N d L}^{3}\left(\lambda_{\mathrm{em}}: 1065 \mathrm{~nm}\right.$ and $\lambda_{\mathrm{ex}}: 450 \mathrm{~nm}$ ) and (b) RuL $\mathbf{L}^{2}-\mathbf{N d L} \mathbf{L}^{4}$ $\left(\lambda_{\mathrm{em}}: 1066 \mathrm{~nm}\right.$ and $\left.\lambda_{\mathrm{ex}}: 450 \mathrm{~nm}\right)$ complexes in solid state. 
Table 1. Photophysical properties for MLCT-based visible emission and neodymium(III) based NIR. Lifetimes data $(\tau)$ were obtained for ruthenium(II) and heterobimetallic complexes in solid state

\begin{tabular}{lcccc}
\hline & \multicolumn{4}{c}{ MLCT-based emission $\left(\lambda_{\mathrm{Ex}} 448 \mathrm{~nm}\right)$} \\
\cline { 2 - 5 } & $\lambda / \mathrm{nm}$ & $\tau / \mathrm{ns}$ & $\mathrm{k}_{\mathrm{EnT}}{ }^{\mathrm{a}} /\left(10^{7} \mathrm{~s}^{-1}\right)$ & $\eta_{\mathrm{EnT}}{ }^{\mathrm{b}} / \%$ \\
\hline $\mathrm{RuL}^{1}$ & 670 & 128.1 & - & - \\
$\mathrm{RuL}^{1}-\mathrm{NdL}^{3}$ & 670 & 72.0 & 0.61 & 43.8 \\
$\mathrm{RuL}^{2}$ & 620 & 178.8 & - & - \\
$\mathrm{RuL}^{2}-\mathrm{NdL}^{4}$ & 620 & 27.8 & 3.04 & 84.4 \\
\hline
\end{tabular}

${ }^{a} \mathrm{k}_{\mathrm{EnT}}$ (energy transfer rate constant $)=1 / \tau_{\mathrm{q}}-1 / \tau_{\mathrm{u}}\left(\tau_{\mathrm{q}}\right.$ and $\tau_{\mathrm{u}}$ refer to the "quenched" and "unquenched" lifetime of ruthenium(II) complexes before and after coordination with lanthanide(III)); ${ }^{\mathrm{b}} \eta_{\mathrm{EnT}}$ (efficiency of energy transfer $)=1-\left(\tau_{\mathrm{q}} / \tau_{\mathrm{u}}\right)$. MLCT: metal-to-ligand charge transfer.

the $\mathrm{k}_{\mathrm{EnT}}$ and $\eta_{\mathrm{EnT}}$ were $3.04 \times 10^{7} \mathrm{~s}^{-1}$ and $84 \%$, respectively. For $\mathrm{RuL}^{1}$ complex, the ${ }^{3} \mathrm{MLCT}$ energy level is located at $14925 \mathrm{~cm}^{-1}$. Values of $\mathrm{k}_{\mathrm{EnT}}$ and $\eta_{\mathrm{EnT}}$ for the $\mathrm{RuL}^{1}-\mathrm{NdL}^{3}$ were $0.61 \times 10^{7} \mathrm{~s}^{-1}$ and $44 \%$, respectively. It is worth emphasizing that higher EnT rate was observed for $\mathrm{RuL}^{2}-\mathrm{NdL}^{4}$ complex. This observation could be explained considering that neodymium(III) presents excited levels better located for energy transfer from RuL ${ }^{2}{ }^{3}$ MLCT states.

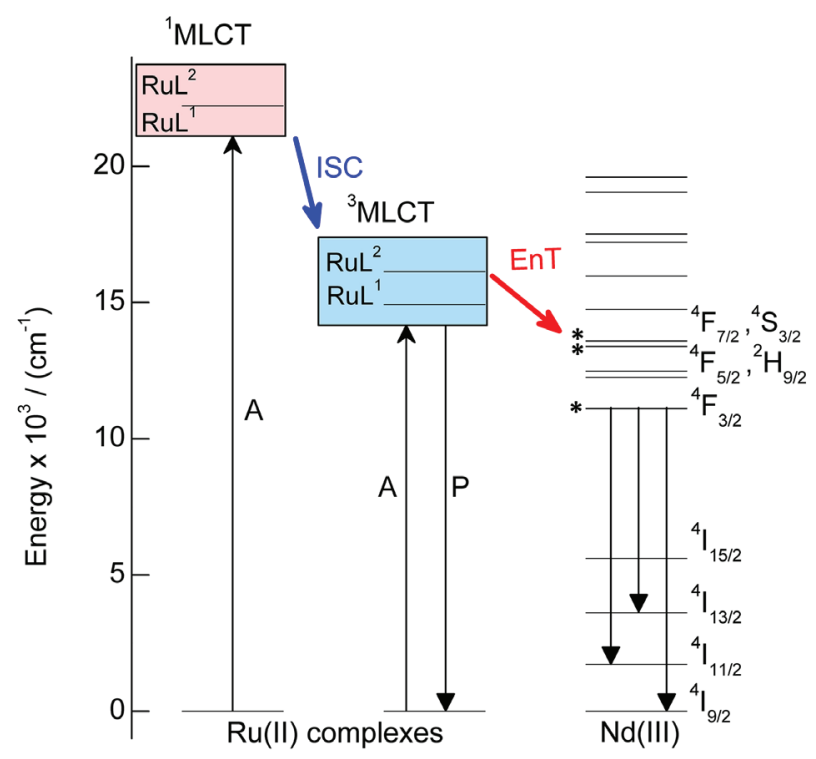

Scheme 2. Schematic energy transfer processes from RuL ${ }^{1}$ and $\mathrm{RuL}^{2}$ complexes (ruthenium(II)) to neodymium(III) (A = absorption; ISC = inter-system cross; $\mathrm{P}=$ phosphorescence; EnT = energy transfer; $\mathrm{F}=$ fluorescence) in the $\mathrm{RuL}^{1}-\mathrm{NdL}^{3}$ and $\mathrm{RuL}^{2}-\mathrm{NdL}^{4}$ complexes.

\section{Conclusions}

New ruthenium(II) complexes, named $\mathrm{RuL}^{1}$ and $\mathrm{RuL}^{2}$, both containing the bridging ligand bpym and the last one containing also a silylated bpy ligand $\left(\mathrm{L}^{2}\right)$ have been prepared. From these complexes and new $\mathrm{NdL}^{3}$ diketonate complexes (where $\mathrm{L}^{3}$ is methoxysilyl modified diketonate), ruthenium(II)-neodymium(III) heteronuclear compounds have been prepared. A structural study was performed by EA, MS, FTIR and FT-Raman and 1D and 2D NMR techniques confirming the presence of the alkoxysilyl function and the fabrication of two new silylated d-f heterobimetallic complexes. UV-Vis spectra depicted characteristic transition bands in ruthenium(II) and neodymium(III) mononuclear precursors and both transition bands contributions in $\mathrm{RuL}^{1}-\mathrm{NdL}^{3}$ and $\mathrm{RuL}^{2}-\mathrm{NdL}^{4}$ complexes corroborating all structural analysis. The luminescent properties of the silylated d-f heterobimetallic complexes were evaluated with energy transfer processes being established from the ruthenium(II) donor to neodymium(III) acceptor units in the IR region. The decrease of lifetime and ruthenium quantum yield resulting from ruthenium(II) units compared to ruthenium(II)neodymium(III) confirm effective energy transfer in these systems. For RuL ${ }^{1}-\mathrm{NdL}^{3}$ complex, $\mathrm{k}_{\mathrm{EnT}}$ and $\eta_{\mathrm{EnT}}$ values of $0.61 \times 10^{7} \mathrm{~s}^{-1}$ and $44 \%$ were obtained whereas $\mathrm{RuL}^{2}-\mathrm{NdL}^{4}$ complex showed $k_{\mathrm{EnT}}$ and $\eta_{\mathrm{EnT}}$ values of $3.04 \times 10^{7} \mathrm{~s}^{-1}$ and $84 \%$, respectively. Our results emphasize that new silylated heterobimetallic ruthenium(II)-neodymium(III) complexes can be excited in the visible range via ruthenium(II) MLCT transitions promoting energy transfer to neodymium(III) units emitting in the IR region. The successful preparation of the silylated ruthenium(II)-neodymium(III) complexes allow grafting onto any silicated matrix suggesting their application as new luminescent NIR-emitting biosensors or biomarkers.

\section{Supplementary Information}

Supplementary data (1D/2D NMR data (Table S1); synthesis routes of the mononuclear precursors, $\mathrm{RuL}^{1}$, $\mathrm{RuL}^{2}$ and $\mathrm{NdL}^{3}$ (Figure $\mathrm{S} 1$ ); $\mathrm{NdL}^{4}$ synthesis route and structure (Figure S2); Raman scattering spectra (Figure S3); 1D/2D NMR spectra (Figures S4-S9); FTIR spectra (Figure S10); luminescence spectra monitoring Ru units of the heterobimetallic complexes (Figure S11) and of the ruthenium(II) precursors complexes (Figure S12)) are available free of charge at http://jbcs.sbq.org.br as PDF file.

\section{Acknowledgments}

This work was supported by the Brazilian agencies FAPESP, CNPq, CAPES and CAPES-COFECUB BrazilFrance cooperation program for grant to R. M. Sábio.

\section{References}

1. Chen, F.-F.; Chen, Z.-Q.; Bian, Z.-Q.; Huang, C.-H.; Coord. Chem. Rev. 2010, 254, 991. 
2. Chen, F.-F.; Wei, H.; Bian, Z.; Liu, Z.; Ma, E.; Chen, Z.; Huang, C.; Organometallics 2014, 33, 3275.

3. Jana, A.; Baggaley, E.; Amoroso, A.; Ward, M. D.; Chem. Commun. 2015, 51, 8833.

4. Baggaley, E.; Cao, D.-K.; Sykes, D.; Botchway, S. W.; Weinstein, J. A.; Ward, M. D.; Chem. - Eur. J. 2014, 20, 8898.

5. Pope, S. J. A.; Coe, B. J.; Faulkner, S.; Laye, R. H.; Dalton Trans. 2005, 1482.

6. Li, L.; Zhang, S.; Xu, L.; Chen, Z.-N.; Luo, J.; J. Mater. Chem. C 2014, 2, 1698 .

7. Lazarides, T.; Sykes, D.; Faulkner, S.; Barbieri, A.; Ward, M. D.; Chem. - Eur. J. 2008, 14, 9389.

8. Shavaleev, N. M.; Accorsi, G.; Virgili, D.; Bell, Z. R.; Lazarides, T.; Calogero, G.; Armaroli, N.; Ward, M. D.; Inorg. Chem. 2005, 44,61 .

9. Lazarides, T.; Tart, N. M.; Sykes, D.; Faulkner, S.; Barbieri, A.; Ward, M. D.; Dalton Trans. 2009, 3971.

10. Lazarides, T.; Adams, H.; Sykes, D.; Faulkner, G.; Calogero, A.; Ward, M. D.; Dalton Trans. 2008, 691.

11. Zucchi, G.; le Goff, X. F.; Polyhedron 2013, 52, 1262.

12. Zucchi, G.; Maury, O.; Thuéry, P.; Ephritikhine, M.; Inorg. Chem. 2008, 47, 10398.

13. Ward, M. D.; Coord. Chem. Rev. 2010, 254, 2634.

14. Fratini, A.; Richards, G.; Larder, E.; Swavey, S.; Inorg. Chem. 2008, 47, 1030.

15. Wei, Q.-H.; Lei, Y.-F.; Xu, W.-R.; Xie, J.-M.; Chen, G.-N.; Dalton Trans. 2012, 41, 11219.

16. Cousinié, S.; Gressier, M.; Alphonse, P.; Menu, M.-J.; Chem. Mater. 2007, 19, 6492.
17. Duarte, A. P.; Gressier, M.; Menu, M.-J.; Dexpert-Ghys, J.; Caiut, J. M. A.; Ribeiro, S. J. L.; J. Phys. Chem. C. 2012, 116, 505.

18. Cousinié, S.; Mauline, L.; Gressier, M.; Kandibanda, S. R.; Datas, L.; Reber, C.; Menu, M.-J.; New J. Chem. 2012, 36, 1355.

19. Sábio, R. M.; Gressier, M.; Caiut, J. M. A.; Menu, M.-J.; Ribeiro, S. J. L.; Mater. Lett. 2016, 174, 1.

20. Cousinié, S.; Gressier, M.; Reber, C.; Dexpert-Ghys, J.; Menu, M.-J.; Langmuir 2008, 24, 6208.

21. Duarte, A. P.; Mauline, L.; Gressier, M.; Dexpert-Ghys, J.; Roques, C.; Caiut, J. M. A.; Deffune, E.; Maia, D. C. G.; Carlos, I. Z.; Ferreira, A. A. P.; Ribeiro, S. J. L.; Menu, M.-J.; Langmuir 2013, 29, 5878.

22. Mauline, L.; Gressier, M.; Roques, C.; Hammer, P.; Ribeiro, S. J. L.; Caiut, J. M. A.; Menu, M.-J.; Biofouling 2013, 29, 775.

23. Silverstein, D. W.; Milojevich, C. B.; Camden, J. P.; Jensen, L.; J. Phys. Chem. C 2013, 117, 20855.

24. Kokošková, M.; Procházka, M.; Šloufová, I.; Vlčková, B.; J. Phys. Chem. C 2013, 117, 1044.

25. Zhang, L.-Y.; Hou, Y.-J.; Pan, M.; Chen, L.; Zhu, Y.-X.; Yin, S.-Y.; Shao, G.; Su, C.-Y.; Dalton Trans. 2015, 44, 15212.

26. Singaravadivel, S.; Babu, E.; Velayudham, M.; Lu, K.-L.; Rajagopal, S.; J. Organomet. Chem. 2013, 738, 49.

Submitted: April 23, 2019 Published online: October 1, 2019 